INTERNATIONAL JOURNAL OF RESEARCHES IN BIOSCIENCES, AGRICULTURE AND TECHNOLOGY (C) VISHWASHANTI MULTIPURPOSE SOCIETY (Global Peace Multipurpose Society) R. No. MH-659/13(N) www.vmsindia.org

\title{
Synthesis and Characterization of Different Amides Via Biginelli
}

\author{
Y. K. Meshram, S. B. Rewatkar, G. R. Nimbarte and A. R. Gaurkar \\ G.S.Science, Art's and Commerce College, Khamgaon,Buldhana, Maharshtra (India) \\ yuvrajmeshram@gmail.com
}

\begin{abstract}
:
P. Biginelli in 1893 reported the synthesis of functionalized 3,4-dihydropyrimidin-2(1H)-ones (DHMPs) via three component condensation reaction of an aromatic aldehyde, urea and the ethyl acetoacetate. The yields of the dihydropyrimidinones obtained via this novel protocol are significantly higher than those utilizing the conventional ethanol / $\mathrm{HCl}$ method. A simple and economic synthesis of 3,4-dihydropyrimidin-2(1H)-ones by using phosphorus pentaoxide. The phosphorus pentaoxide can be converted into the phosphoric acid. The phosphorus pentaoxide has been found to be mild and efficient reagent for the synthesis of dihydropyrimidinones and its corresponding thioanalogs in refluxing ethanol. These are become popular in the world of synthetic organic chemistry due to their activities such as antibacterial, anti-viral, anti-inflametory. A series of the new 5-amido-4(phenyl)-6-methyl,3,4dihydropyrimidin-2(1H)-ones have been synthesized by using the 5-ethoxycarbonyl-4(phenyl)-6-methyl,3,4dihydropyrimidin-2 $(1 \mathrm{H})$-ones and the excess amount of the ammonia. The different compounds of this series can be synthesized by using one-pot multicomponent synthesis. The newly synthesized different amide derivatives of the 3,4, dihydropyrimidin-2 $(1 \mathrm{H})$-one were well monitor by using TLC plates. And these synthesized compounds were well characterized by $1 \mathrm{H}-\mathrm{NMR}$ spectral studies. The results of such compound have been discussed in this paper. In the conclusion, we have developed a simple, quick a one pot multicomponent synthesis and characterization of different amide via Biginelli.
\end{abstract}

Keywords : Phosphoric acid, ammonia, one-pot synthesis, Biginelli reaction etc.

\section{Introduction :}

The synthesis of dihydropyrimidinones and their thio-analogous have become more popular in the world of synthetic organic chemistry due to their activities such as antibacterial, antiviral, antihypertensive, antiinflammatory, antitumor[1]. Although the mechanism of Biginelli reaction has been debated for a number of years, most researchers now agree on the following sequence of steps, as proposed by Kappe[2]. The Biginelli reaction produces a 3,4-dihydropyrimidinone, an example of class of compounds exhibiting the pharmacological activity. Recently some marine alkaloids possess dihydropyrimidin-5carboxylate core have been shown to exibit interesting biological activities such as potent HIV-gp-120-CD4 inhibitors as well as anti HIV agent [3]. An efficient synthesis of dihydropyrimidin-2 $(1 \mathrm{H})$-ones using the phosphorus pentaoxide was studied by Deshmukh and etal [4]. And thus we have requires the development of new protocol for high yield and the use of inexpensive reagent, which requires shorter time and with easier work-up procedure, A few method involves the use of ionic crystals.[5].

Multicomponent reactions (MCRs) are of increasing importance in organic and medicinal chemistry. [6-10] In such reactions, three or more reactants come together in a single reaction vessel to form new products that contain portion of all the components. [6-10] The search and discovery for new MCRs on one hand[11], and the full exploitation of already known multicomponent reactions on the other hand, is therefore of considerable current interest. The recent advances in the Biginelli Dihydropyrimidine synthesis again C. Oliver Kappe proposed a new tricks for the same dihydropyrimidine synthesis from an old dog[11]. The heterocyclic system constitute privileged substructures and are present in a large number of compounds with remarkable biologicl activity [12]. Although, the MCR strategy is a highly desirable approach in drug discovery development in the context of rapid identification, structural diversification and optimization of biologically active lead compounds of potential therapeutic importance within a short span of time which can generate large number of libraries of heterocyclic compounds with the aid of high through put biological screening .

\section{Result and Discussion:}

The phosphoric acid is an on expensive reagent acts as an acid and the dehydrating reagent also. In the presence of the phosphoric acid the Biginell Reaction Satisfactory fulfilled the entire above requirements. The phosphoric acid increases in the acidic condition of the reaction mixture and due to which the rate of the reaction is increases which leads to shorter reaction time.

In this communication, we report the used of phosphoric acid for one pot multicomponent synthesis of 3,4 dihydropyrimidinones. As in the trial case, benzaldehyde (1.06 gm, $10 \mathrm{~m}$ moles), ethyl 
acetoacetate ( $1.30 \mathrm{gm}, 10 \mathrm{~m}$ moles), urea (1.80 gm,30 m moles )and phosphoric acid ( $0.5 \mathrm{gm}$, $30.54 \mathrm{~m}$ moles) urea mixed thoroughly and the reaction mixture refluxed on water bath. After the completion of the reaction, the mixture was poured on the crushed ice (100 gm) after the stirring the desired dihydropyrimidinones separated out as a white solid in the quantitative yield. ( Scheme - 1 ) However excess addition of phosphoric acid does not increases the yield of product.

Effect of the amount of the phosphoric acid on the yield of 3,4-dihydropyrimidin-2(1H)one was investing by using amount of phosphoric acid.

In this (Scheme-II) again the excess amount of the addition of ammonia does not affect the yield of reaction.

\section{Scheme: I}

Table:1 Data for the synthesis of corresponding 3,4-dihydropyrimidin-2(1H)-one in the presence of phosphoric acid :

\begin{tabular}{|c|c|c|c|c|c|c|}
\hline Entry & $\mathbf{R}$ & $\mathbf{R}^{\prime}$ & $\mathbf{x}$ & Time(hrs) & \% Yield & M.P.(OC) \\
\hline 1 & $\mathrm{C}_{6} \mathrm{H}_{5}$ & OEt & $\mathrm{O}$ & 1.0 & $95 \%$ & $203-204(204){ }^{\circ} \mathrm{C}$ \\
\hline 2 & $4\left(\mathrm{NO}_{2}\right)-\mathrm{C}_{6} \mathrm{H}_{4}$ & OEt & $\mathrm{O}$ & 1.0 & $95 \%$ & $207-208(210){ }^{\circ} \mathrm{C}$ \\
\hline 3 & $3\left(\mathrm{OCH}_{3}\right)-\mathrm{C}_{6} \mathrm{H}_{4}$ & ${ }_{4} \mathrm{OEt}$ & $\mathrm{O}$ & 1.45 & $89 \%$ & $189-190(190)^{\circ} \mathrm{OC}$ \\
\hline 4 & $4\left(\mathrm{OC}_{2} \mathrm{H}_{5}\right)-\mathrm{C}_{6} \mathrm{H}$ & $4 \mathrm{OEt}$ & $\mathrm{O}$ & 1.45 & $90 \%$ & $196-197(195)$ OC \\
\hline 5 & $4(\mathrm{Cl})-\mathrm{C}_{6} \mathrm{H}_{4}$ & $\mathrm{OEt}$ & $\mathrm{O}$ & 0.5 & $95 \%$ & $217-218(210){ }^{\circ} \mathrm{C}$ \\
\hline 6 & $\mathrm{C}_{6} \mathrm{H}_{5}$ & $\mathrm{Me}$ & $\mathrm{O}$ & 1.50 & $90 \%$ & $207-208(210)^{\circ} \mathrm{C}$ \\
\hline 7 & $4\left(\mathrm{NO}_{2}\right)-\mathrm{C}_{6} \mathrm{H}_{4}$ & $\mathrm{Me}$ & $\mathrm{O}$ & 3.0 & $80 \%$ & $188-189(190)$ OC \\
\hline 8 & $4(\mathrm{OH})-\mathrm{C}_{6} \mathrm{H}_{4}$ & $\mathrm{Me}$ & $\mathrm{O}$ & 3.30 & $80 \%$ & $209{ }^{\circ} \mathrm{C}$ \\
\hline 9 & $4(\mathrm{OCH} 3)-\mathrm{C}_{6} \mathrm{H}_{4}$ & $\mathrm{OEt}$ & $\mathrm{O}$ & 1.5 & $90 \%$ & $203{ }^{\circ} \mathrm{C}$ \\
\hline 10 & $4(\mathrm{Br})-\mathrm{C}_{6} \mathrm{H}_{4}$ & OEt & $\mathrm{O}$ & 2.0 & $92 \%$ & $216{ }^{\circ} \mathrm{C}$ \\
\hline 11 & $2(\mathrm{Cl})-\mathrm{C}_{6} \mathrm{H}_{4}$ & OEt & $\mathrm{O}$ & 1.20 & $88 \%$ & $218^{\circ} \mathrm{C}$ \\
\hline 12 & 4(F)-C6H4 & OEt & $\mathrm{O}$ & 1.40 & $86 \%$ & $207{ }^{\circ} \mathrm{C}$ \\
\hline
\end{tabular}

Where $\mathrm{R}^{\prime}=\mathrm{OCH}_{3}$ or $\mathrm{OC}_{2} \mathrm{H}_{5}$

$\mathrm{R}=\mathrm{Ph}$ or alkyl group

Table:1 Data for the synthesis of different amide from 3,4-dihydropyrimidin-2(1H)-one :

\begin{tabular}{|c|c|c|c|c|c|c|}
\hline Entry & $\mathbf{R}$ & $\mathbf{R}^{\prime}$ & $\mathbf{x}$ & Time(hrs) & \% Yield & M.P.(OC) \\
\hline 1 & $\mathrm{C}_{6} \mathrm{H}_{5}$ & OEt & $\mathrm{O}$ & 3.50 & $90 \%$ & $189{ }^{\circ} \mathrm{C}$ \\
\hline 2 & $4\left(\mathrm{NO}_{2}\right)-\mathrm{C}_{6} \mathrm{H}_{4}$ & OEt & $\mathrm{O}$ & 3.40 & $90 \%$ & $202{ }^{\circ} \mathrm{C}$ \\
\hline 3 & $4\left(\mathrm{OCH}_{3}\right)-\mathrm{C}_{6} \mathrm{H}_{4}$ & OEt & $\mathrm{O}$ & 3.10 & $92 \%$ & $212^{\circ} \mathrm{C}$ \\
\hline 4 & $4(\mathrm{Br})-\mathrm{C}_{6} \mathrm{H}_{4}$ & OEt & $\mathrm{O}$ & 3.30 & $90 \%$ & $201{ }^{\circ} \mathrm{C}$ \\
\hline 5 & $4(\mathrm{OH})-\mathrm{C}_{6} \mathrm{H}_{4}$ & OEt & $\mathrm{O}$ & 3.45 & $83 \%$ & $235^{\circ} \mathrm{C}$ \\
\hline 6 & $4(\mathrm{Cl})-\mathrm{C}_{6} \mathrm{H}_{4}$ & OEt & $\mathrm{O}$ & 4.00 & $92 \%$ & $222^{\circ} \mathrm{C}$ \\
\hline 7 & $2(\mathrm{Cl})-\mathrm{C}_{6} \mathrm{H}_{4}$ & OEt & $\mathrm{O}$ & 3.50 & $90 \%$ & $213^{\circ} \mathrm{C}$ \\
\hline 8 & $4\left(\mathrm{OC}_{2} \mathrm{H}_{5}\right)-\mathrm{C}_{6} \mathrm{H}_{4}$ & OEt & $\mathrm{O}$ & 3.20 & $90 \%$ & $192{ }^{\circ} \mathrm{C}$ \\
\hline 9 & $4(\mathrm{~F})-\mathrm{C}_{6} \mathrm{H}_{4}$ & OEt & $\mathrm{O}$ & 3.50 & $85 \%$ & 198 OC \\
\hline 10 & $4(\mathrm{I})-\mathrm{C}_{6} \mathrm{H}_{4}$ & OEt & $\mathrm{O}$ & 3.50 & $80 \%$ & 209 OC \\
\hline 11 & $3\left(\mathrm{NO}_{2}\right)-\mathrm{C}_{6} \mathrm{H}_{4}$ & OEt & $\mathrm{O}$ & 3.25 & $89 \%$ & 197 OC \\
\hline 12 & $3(\mathrm{Br})-\mathrm{C}_{6} \mathrm{H}_{4}$ & OEt & $\mathrm{O}$ & 3.30 & $84 \%$ & $213^{\circ} \mathrm{C}$ \\
\hline
\end{tabular}

\section{Experimental Section :}

All the compounds are reported one and their melting points are matched with reported value. All the above products have been characterized by proton NMR. The $1 \mathrm{H}-\mathrm{NMR}$
As per our observation $100 \mathrm{mg}$ phosphoric acid gives $30-40 \%$ yield, $200 \mathrm{mg}$ of phosphoric acid gives $55-60 \%$ yield, $300 \mathrm{mg}$ gives $60-70 \%$ yield ,400mg gives $75-80 \%$ yield while $500 \mathrm{mg}$ of phosphoric acid gives $85-90 \%$ yield in the refluxing ethanol. Using the optimized quantity of the phosphoric acid was extended to a variety of aldehyde including aromatic, aliphatic, as well as heterocyclic aldehydes to afford corresponding dihydropyrimidinones in the excellent yields. The versatility of the method was then checked by using thio urea instead of urea to prepare dihydropyrimidinones and by replacing EAA with MAA. Which gave the corresponding DHPMs. Both these variations did not affect appreciably the yield as well as case of work up procedure. And these result are summarized in Table -1 


\section{General Procedure :}

For Scheme-I, the mixture of an aldehyde(10mmoles), urea/thiourea (30mmoles), ethyl acetoacetate/ acetyl acetone (10mmoles) and the phosphoric acid (0.5 gm, 3.54 mmoles) in a $250 \mathrm{ml}$ round bottom flask refluxed on water bath, cooled and the reaction mixture was poured on crushed ice. The separated solid was then filtered, washed with pet ether, dried and recrystalized using ethanol.

For Scheme-II, The mixture of an dihydropyrimidinones(0.75 gm) and ammonia $(15-20 \mathrm{ml})$ in a $250 \mathrm{ml}$ round bottom flask and refluxed on water bath, cooled the flask and the given mixture is added into the crushed ice (100gm).

The separated solid was then filtered, washed with pet ether, then dry the product and recrystalized by using ethanol.

\section{Spectroscopic Data of Different Compounds} :-

Scheme-I (Spectroscopic Data of Representative DHPMs)

1) 5-Ethylcarbonyl-4( phenyl)-6-methyl,3,4dihydropyrimidine-2 $(1 \mathrm{H})$-one (Entry 1):m.p. $203-204^{\circ} \mathrm{c}$ (Lit m. p. $204^{\circ} \mathrm{C}$ ) PMR (DMSO) : $5.3(1 \mathrm{H}, \mathrm{bs}, \mathrm{NH}), \quad 7.39(5 \mathrm{H}, \mathrm{m}, \mathrm{ArH}), 8.24(1 \mathrm{H}, \quad \mathrm{bs}$, $\mathrm{NH}), 2.34\left(3 \mathrm{H}, \mathrm{SCH}_{3}\right), 1.16\left(3 \mathrm{H}, \mathrm{t}, \mathrm{COCH}_{2} \mathrm{CH}_{3}\right)$.

2) 5-Ethylcarbonyl4-(4-nitrophenyl)-6-methyl3,4 dihydropyrimidin-2(1H)-one (Entry 2):m. p. $207-208^{\circ} \mathrm{C}$ (Lit. m. p. $210^{\circ} \mathrm{c}$ ) PMR (DMSO) :5.1 $(1 \mathrm{H}, \mathrm{bs}, \mathrm{NH}), 7.2 \quad(5 \mathrm{H}, \mathrm{m}, \mathrm{ArH}), \quad 9.1 \quad(1 \mathrm{H}, \mathrm{bs}, \mathrm{NH})$, $2.25\left(3 \mathrm{H}, \mathrm{S}, \mathrm{CH}_{3}\right), 1.12\left(3 \mathrm{H}, \mathrm{t}, \mathrm{COCH}_{2} \mathrm{CH}_{3}\right)$.

3) 5-Ehoxycarbonyl-4-(4-ethoxyphenyl)-6methyl-3,4 dihyropyrimidin-2(1H)-one (Entry 4 ) : m. p. $196-197^{\circ} \mathrm{c}$ (Lit. m. p. $195^{\circ} \mathrm{C}$ ) PMR( DMSO): 5.1, (1H,bs, NH), $7.1 \quad(5 \mathrm{H}, \quad \mathrm{m}, \mathrm{ArH})$, 9.1(1H,bs, $\mathrm{NH})$, $2.5\left(3 \mathrm{H}, \mathrm{S}, \mathrm{CH}_{3}\right)$, $1.12\left(3 \mathrm{H}, \mathrm{t}, \mathrm{COCH}_{2} \mathrm{CH}_{3}\right)$.

4) 5-Ethoxycarbonyl-4-(2-Chlorophyenyl) -6 methyl- 3,4 dihydropyrimidin-2 $(1 \mathrm{H})$-one (Entry 11): m. p. $217-218^{\circ} \mathrm{c}$ (Lit. m. p. $210^{\circ} \mathrm{c}$ ) $\mathrm{PMR}($ DMSO): 5.6, (1H,bs, NH), 7.3 (5H,m, ArH), 9.2 $(1 \mathrm{H} \quad$ bs, $\mathrm{NH}) \quad 2,29 \quad\left(3 \mathrm{H}, \quad \mathrm{S}, \mathrm{CH}_{3}\right), \quad 101 \quad(3 \mathrm{H}, \mathrm{t}$, $\mathrm{COCH}_{2} \mathrm{CH}_{3}$ ).

Scheme-II (Spectroscopic Data of Different Amides)

1) 5-amido-4(phenyl) 6-methyl,3,4dihydropyrimidin $\quad-2 \quad(1 \mathrm{H})$-one $\quad$ (entry 1) : M.P.(189 OC ) PMR(DMSO): 5.3(1H, bs, NH), 7.39(5H, m, ArH $), 8.24(1 \mathrm{H}, \mathrm{bs}, \mathrm{NH})$, $2.34\left(3 \mathrm{H}, \mathrm{S}, \mathrm{CH}_{3}\right), 1.16\left(3 \mathrm{H}, \mathrm{t}, \mathrm{COCH}_{2} \mathrm{CH}_{3}\right)$.

2) 5-amido-4(4-methoxy phenyl)6-methyl,3,4dihydropyrimidin-2(1H)-one (entry 3) :M.P.(212 oC)PMR (DMSO):5.1(1 H, bs, $\mathrm{NH}), 7.1(5 \mathrm{H}, \mathrm{m}, \mathrm{ArH})$, 9.1(1H,bs, NH), 2.5(3H,s, CH3), $1.12(3 \mathrm{H}, \mathrm{t}, \mathrm{COCH} 2 \mathrm{C}$ H3

\section{Acknowledgement:-}

The authors are very thankful to the Principal of G. S. Science, Arts and Commerce College, Khamgaon, for providing the necessary facilities in the Laboratory and also to, CDRI, Lucknow for providing the spectral analysis.

\section{References :-}

1) (a) Kato T, Japan Kokai Tokkyo Koho, 1984 JP, [ Chem. Abstr., 102 : 1320, 67, 1985]59, $1984,190,974$.

(b) Atwal $\mathrm{K}$ S, Swanson BN , Unger SE, Floyd, DM, Moreland, S, Hedberg A and $O$ " Reilly BC, J>med Che. 34,1991,806.

2) Kappe, C.O.J.Org. Chem. 1997,62,7201.

3)(a) Perrellx L. and Loupy A, Terahedron, 57,2001.9199;

(b) Lidstrom p,Tierney, $\mathbf{J}$ and Wathey $B$, Westman J, Tetrahedron, 57,2001,9225.

4) (a) Ghosh R, Maith S and Chakraborty A, J mol Catalysis, 27,2004,47;

(b) Yarapathi R. V. Kurva $\mathbf{S}$ and tammishelti $\mathbf{S}$, Cat Commun, 5, 2004, 511.

(c) Atwal K S , Rovnyak G C, O" Reilly B. c and Schwwdz j, J, Org Chem, 54,1989, 5898.

5) (a) Salehi H Guo, Q Synth Commun, 34(1), 2004, 171;

(b) Tu S, Fang F, Zhu S, Li, T, Zhang $X$ and Zhuaga Q. Synlett, 2004, 537;

(c) Hazarkhani $\mathbf{H}$ and Karimi B, Synthesis, $8,2004,1239$.

6) Armstrong, R.W.; Combs, A.P.; Tempest, P.A.; Brown, S.D.; Keating, T.A. Multiple component condensation strategies for combinational library synthesis. Acc. Chem. Res. 1996,29,123-131.

7) Ugi,I.; Domling, A.; Horl, W. Multicomponent Reactions in organic chemistry. Endeavour $1994,18,115-122$.

8) Dax, S.L.; McNally, J.J.; Youngman, M.A. Multi-component Methodologies in solid phase organic synthesis. Curr. Opin. Chem.Biol. 1999,6,255-270.

9) Tietze, L.F.; Lieb, M.E. Domino Reactions for library synthesis of small molecules in combinatorial chemistry. Curr. Opin. Chem.. Biol. 1998,2,363-371.

10) Domling. A. Isocyanide Based Multi component Reactions in combinatorial chemistry. Comb. Chem.. high throughput screening 1998,1,1-22.

11) Weber, L; lllgen, k; Almstetter, M. Discovery of New Multicomponent Reactions with combinatorial Methods. Synlett 1999,3,366-374.

12) Eicher T, Hauptmanns, The chemistry of Heterocydes, $2^{\text {nd }}$ ed, Wiley-VCH: Weinheim, Germany, 2003,pp 316. 